症例

早期に術前診断された胆襄癌と胆管癌の各 1 例

\author{
都立豊島病院外科 唐 木一守佐々木 专 也 \\ 都立豊島病院内科 新 田 義 朗
}

\title{
CARCINOMAS OF THE GALLBLADDER AND THE BILE DUCT EACH DIAGNOSED PREOPERATIVELY IN EARLY STAGE
}

\author{
Kazumori KARAKI and Hiroshi SASAKI \\ Department of Surgery, Tokyo Metropolitan Toshima Hospital \\ Yoshiro NITTA \\ Department of Medicine, Tokyo Metropolitan Toshima Hospital
}

術前にX線診断された比較的早期の胆䔄癌と胆管癌の各 1 例を報告した。

症例 1. 68㗤, 男性. 1 年前より心窩部痛または右季肋部痛があり, 胆石症の疑で入院 した. 点滴胆道造影法で胆春底部の辺緑が不整で造影む不十分であり，隆起性病变が疑わ れた. 逆行性胆道造影法と経皮的胆道造影法により胆烡底部の陰影欠損を認め, 胆重癌と 診断した. 胆衰摘出術とリンパ節部清 $(12,8)$ を行った. 組織訩断は乳頭管状腺癌で, 将膜下まで浸潤を認めたが，晞清リンパ節に転移を認めなかった，術後 5 年以上経過し， 健在である.

症例 2. 65歳，女性. 6 カ月前に近医に黄疸を指摘されたが，問むなく軽快した．その 後肝腫大を指摘され，精査の目的で入院した，入院時血清黄庭指数は正常であったが， Al-P, LAP, $\gamma$-GTP 值の高度上算を認めた。 逆行性胆道造影法と 释皮的胆道造影法で三 管合游部に限局した陰影欠損を認め，胆管癌と猃断した。胆衰胆管切除術を行ったが，リ

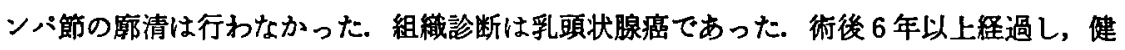
在である.

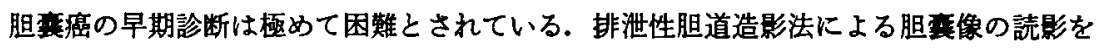
慎重に行らことと，疑わしいものには啧音波検査，直接胆道造影法を積極的に行らことに より，早期の胆桽癌を発見しらる。

黄病の発現した時点で胆管癌を診断することは困難ではないが, 黄疸を伴った胆管癌は 進行癌が多い. 血清 A1-P, LAP, $\boldsymbol{\gamma}$-GTP 等の胆管系醅素値の上昇のみを示す症例に, 直 接胆道造影法を行うことにより, 早期の胆管癌を発見しらろ.

\section{草}

従来, 胆道癌は早期診断が困難で, 治空切除例が少な く，遠隔成績も極めて不良とされていた。しかし，近年 は診断法の進歩と共に早期癌症例, 術後長期生存例の報 告がなされるようになった。われわれる，術前に診断さ れ, 術後 5 年以上健在である, 比較的早期の胆雚癌と胆
管癌の各 1 例を経験したので，若干の文献的考察を加え 報告する.

手術所見，手術手技および切除漂本所見の記載は胆道 癌取扱い規約”に従った。

\section{应 例}

应列 168 歳, 男性. 
家族歴，既往歴：特記するすのなし．

主 訴: 心演部痛, 右季肋部痛.

現病歴：1 年前より時々食後20〜30分間心䈑部痛京た は右季助部痛があり，時に呕気，呕吐を伴った。胆石症 の疑で，昭和51年 5 月11日に当院内科に入院した。

入院時現症：身長 $158 \mathrm{~cm}$, 体重 $56 \mathrm{~kg}$, 栄盖良好. 眼䀫 結膜に貧血なく，球結膜に 黄疸を認めなかった．舌に 白苔を認め，右季肋部に圧痛を認めた．血压128一80 mmHg.

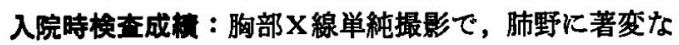
く，心電図は正常範囲であった，血液理化学的，尿，便 検査成積は表 1 に示す.

点激胆道造影法 (DIC) : 胆衰は造,影良好で 变形もな いが，底部の辺縁が不整で造影す不十分であり，隆起性 病変が疑かれた（図け）. 胆管には著变を認めなかった。

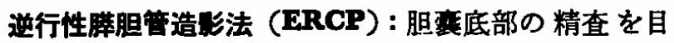
的として行った．DICで疑詥をおいた部分に辺縁不整の 隆起性病変を認めた。

経皮的胆道造影法 (PTC)：ERCP と同様胆衰底部に 陰影欠損を認めた（図2). また，別に胆咅内に移動す る小透亮像を認めた。

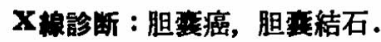

手術：昭和51年 6 月18日に手術を行った。術式は胆咅 摘出術と12(a, b, c, p)，8のリンハ節部清を行なっ た. $\mathrm{S}_{0}, \mathrm{Hinf}_{0}, \mathrm{H}_{0}, \mathrm{~B}_{0}, \mathrm{P}_{0}$ であった。

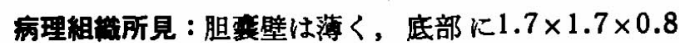

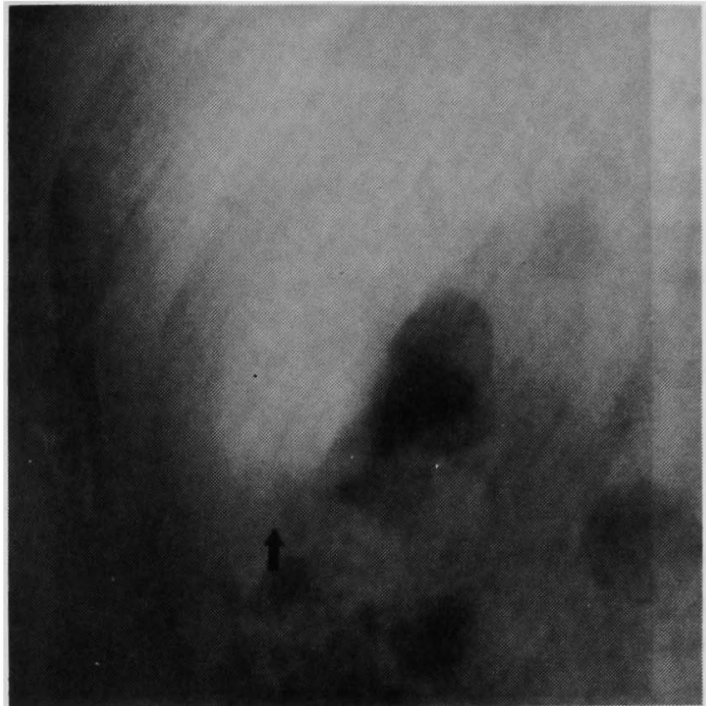

図 1 点滴胆道造影法 矢印は胆率底部の辺緑不整 を示す。

cm の丘状隆起を認めた．組織的には papillotubular adenocarcinoma で（図 3)，墏獏下に小さな carcinoma nests が漫潤している．廊清リンパ節に転移は認めなか った.

術後経過：極めて良好で, 術後 5 年 1 カ月経過した現 在健康である.

应例 2.65歳, 女性.

家族歴：特記するものなし.

表 1 入院時検查成转（应例 1 ）

\begin{tabular}{|c|c|c|c|}
\hline 血色素量 & $12.7 \mathrm{~g} / \mathrm{dl}$ & 総蛋白 & $7.1 \mathrm{~g} / \mathrm{dl}$ \\
\hline 赤血球数 & $435 \times 10^{4} / \mathrm{mm}^{3}$ & $\mathrm{HBs} \mathrm{Ag}$ & $(-)$ \\
\hline 白血球数 & $4,500 / \mathrm{mm}^{3}$ & AFP & $(-)$ \\
\hline ヘマトクリット & $43 \%$ & BUN & $20 \mathrm{mg} / \mathrm{dl}$ \\
\hline 血小板数 & $26.1 \times 10 \% / \mathrm{mm}^{3}$ & 尿 酸 & $2.7 \mathrm{mg} / \mathrm{dl}$ \\
\hline 黄庭指数 & $5 U$ & $\mathrm{Na}$ & $139 \mathrm{mEq} / \mathrm{L}$ \\
\hline ZST & $4.4 \mathrm{U}$ & $\mathrm{K}$ & $3.7 \mathrm{mEq} / \mathrm{L}$ \\
\hline TTT & $2.8 \mathrm{U}$ & $\mathrm{Cl}$ & $107 \mathrm{mEq} / \mathrm{L}$ \\
\hline GOT & $27 \mathrm{U}$ & CRP & $(-)$ \\
\hline GPT & $21 U$ & 赤沈 1 時間 & $26 \mathrm{~mm}$ \\
\hline LDH & $335 \mathrm{U}$ & 2 時間 & $42 \mathrm{~mm}$ \\
\hline Al-P & $12.8 \mathrm{KAU}$ & 尿 & \\
\hline LAP & $184 \mathrm{U}$ & 蛋 白 & $(-)$ \\
\hline$r-G T P$ & $77 \mathrm{U}$ & 榶 & $(-)$ \\
\hline 総コレステロール & $185 \mathrm{mg} / \mathrm{dl}$ & ウロビリノーゲン & $( \pm)$ \\
\hline コリンエステラーゼ & $0.44 \Delta \mathrm{pH}$ & ビリルビン & $(-)$ \\
\hline $\operatorname{ICG}\left(R_{15}\right)$ & $13.1 \%$ & 便 ～～～～～～ & \\
\hline 血清厂ミラーゼ & 257IU/1 & 潜 血 & $(-)$ \\
\hline 血 榶 & $105 \mathrm{mg} / \mathrm{dl}$ & 虫 卵 & $(-)$ \\
\hline
\end{tabular}




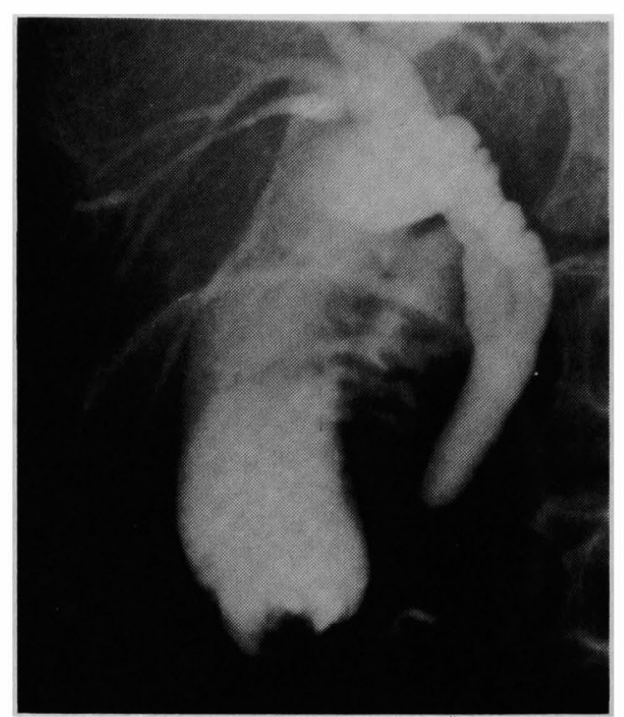

図2 経皮的胆道造影法 胆亳底部に陰影欠損を訆 める.

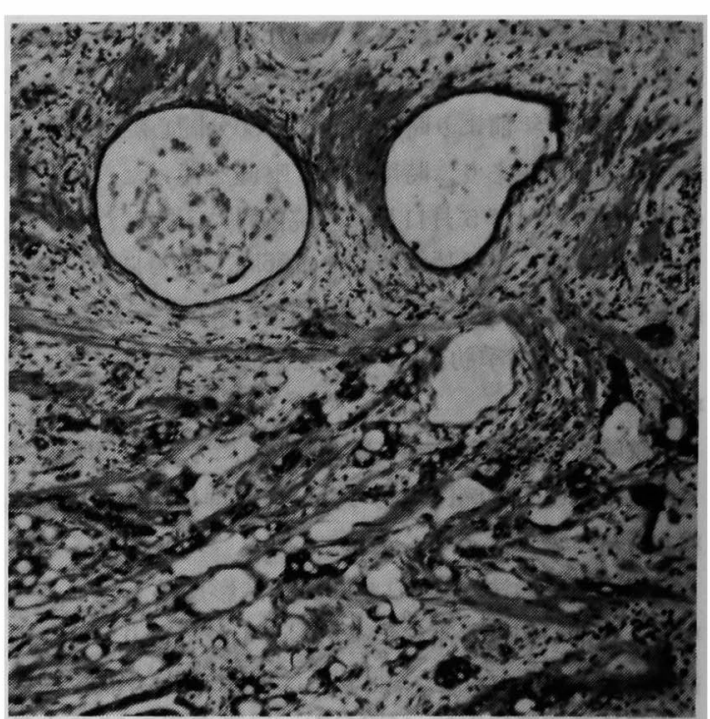

园 3 組暗像

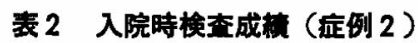

\begin{tabular}{|c|c|c|c|}
\hline 血色菜昌 & $12.7 \mathrm{~g} / \mathrm{dl}$ & \multirow{2}{*}{$\begin{array}{l}\text { 総蛋白 } \\
\mathrm{HBsAg}\end{array}$} & $7.4 \mathrm{~g} / \mathrm{dl}$ \\
\hline 赤血球数 & $419 \times 10^{4} / \mathrm{mm}^{3}$ & & $(-)$ \\
\hline 白血球数 & $6,400 / \mathrm{mm}^{3}$ & AFP & $(-)$ \\
\hline ヘマトクリット & $37 \%$ & BUN & $15 \mathrm{mg} / \mathrm{dl}$ \\
\hline 血小板数 & $43.8 \times 10^{4} / \mathrm{mm}^{3}$ & 尿 酸 & $4.0 \mathrm{mg} / \mathrm{dl}$ \\
\hline 黄疾指数 & $8 \mathrm{U}$ & $\mathrm{Na}$ & $140 \mathrm{mEq} / \mathrm{L}$ \\
\hline ZST & $7.2 \mathrm{U}$ & $\mathrm{K}$ & 4. $3 \mathrm{mEq} / \mathrm{L}$ \\
\hline TTT & $1.1 \mathrm{U}$ & $\mathrm{Cl}$ & $108 \mathrm{mEq} / \mathrm{L}$ \\
\hline GOT & $36 \mathrm{U}$ & CRP & $(-)$ \\
\hline GPT & $58 \mathrm{U}$ & 赤沈 1 時間 & $37 \mathrm{~mm}$ \\
\hline LDH & $276 \mathrm{U}$ & 2 時間 & $73 \mathrm{~mm}$ \\
\hline Al-P & $43.2 \mathrm{KAU}$ & \multicolumn{2}{|l|}{ 沓 } \\
\hline LAP & $793 \mathrm{U}$ & 蛋 白 & $(-)$ \\
\hline$\gamma \cdot \mathrm{GTP}$ & $398 \mathrm{U}$ & 糖 & $(\rightarrow)$ \\
\hline 総コレステロール & $245 \mathrm{mg} / \mathrm{dl}$ & ウロビリノーゲン & （士） \\
\hline コリンエステラーゼ & $0.67 \Delta \mathrm{pH}$ & ビリルビン & $(-)$ \\
\hline ICG $\left(R_{15}\right)$ & $2.1 \%$ & \multicolumn{2}{|l|}{ 便 ～～～～～～} \\
\hline \multirow[t]{2}{*}{ 血＼cjkstart糖 } & $114 \mathrm{mg} / \mathrm{dl}$ & 潜 血 & $(-)$ \\
\hline & & 虫 帠 & $(-)$ \\
\hline
\end{tabular}

既往歴： 2 年前より高血圧で治療中.

主 訴: 一時的黄疸.

現病歴：6カ月前に近医より黄疸を指摘されたが，間 むなく軽快した. 以後, 全く症状がなかったが, 1 カ月 前に尿が番茶様に濃染し，近医に肝腫大を指摘された。 昭和50年 5 月31日, 精査のため当院内科に入院した。

入院時現症 : 身長 $146 \mathrm{~cm}$, 体重 $53 \mathrm{~kg}$ ，栄養良好，やp 肥満気味であった. 眼䀫結膜に貧血なく, 球結膜に黄㾝
を認めなかった，舌に白苔あり，腹部に腫大した胆紊を 触知した. 肝は触れなかった。血圧132-70 $\mathrm{mmHg}$.

入院時検查成䖯 : 胸部X線単純撮影で肺野に異常陰影 なく, 心電図は正常範囲であった. 血液生化学的検査で 黄疸指数は正常であったが，Al-p，LAP， $\gamma$-GTP 值の高 度上昇と, GPT の軽度上昇を認めた（表 2 ）。

ERCP : 総胆管径は約 $9 \mathrm{~mm}$ で, 胆变管合流部近くに 陰影欠損を認めた。胆栾管, 胆重, 肝内胆管は造影され 
なかった．䏾管に異常を諗めなかった。

PTC : 三管合流部と思われる部に 全周性約 $2.5 \mathrm{~cm} の$ 凹凸不整の陰影欠損を琟めるか，造影剂の通過は良好で ある(图4).

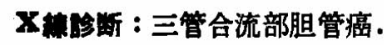

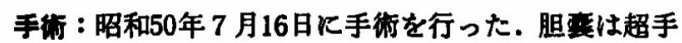
拳大に拡張し, 三管合流部に約 $3 \mathrm{~cm}$ の限局性の腫瘤を 認めた．手術術式は胆亩胆管切除術を行ない, 総肝管空

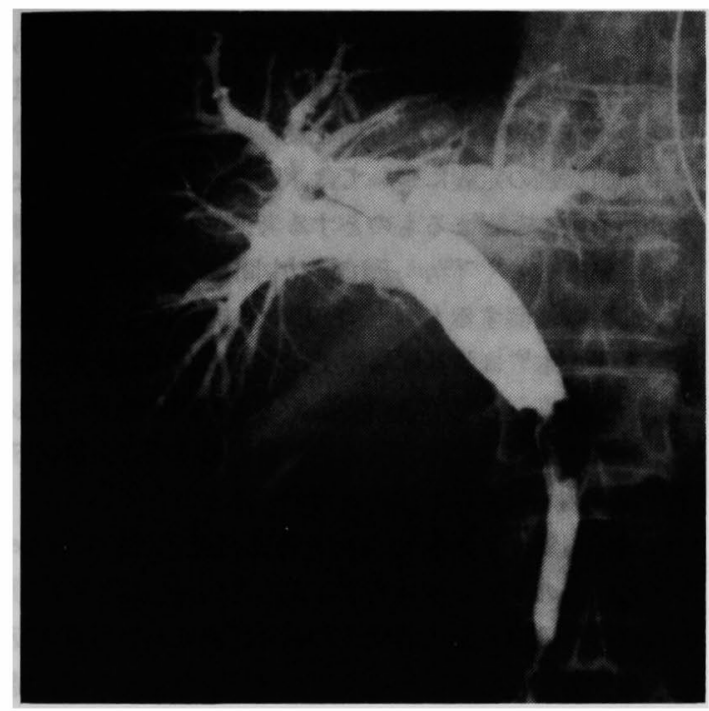

图4怪皮的胆道造影法 三管合流部化全周性の陰 影欠損を訆める。

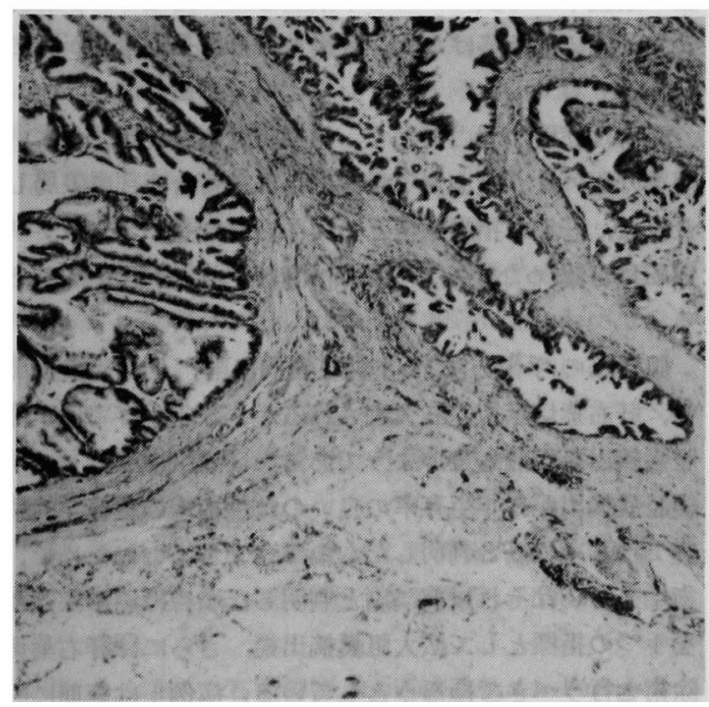

图5 組满像 腸吻合術を行った．小豆大の12c リンパ節を認めたが， 柔かく，他にりンパ節の尰大は認められなかったので， 廊清は行わなかった. $\mathrm{S}_{0}, \mathrm{Hinf}_{0}, \mathrm{H}_{0}, \mathrm{G}_{0}, \mathrm{Panc}_{0}, \mathrm{D}_{0}, \mathrm{~V}_{0}$, P。であった。

病理組雜所見 : 三管合流部の胆管に $3 \mathrm{~cm}$ 長, 全周に わたる，表面出凸不整，一部で乳頭状に突出し，やゃ mucinous な尰瘍を認めた。重坲は分化の良い papillary adenocarcinoma で (図 5)，一部に粘液産生を認めた。 切除断端は HW，DW とも癌浸潤を認めなかった。胆石 は認められなかった。

街後経遗: 術後 6 年の現在健康である.

\section{帣宗}

胆咅癌は全癌の約 3〜 4\%を占め, 肝外胆管癌は胆竞 癌とほぼ同率といわれている゙．金ら”は10年間 (1965 年 1974年）の日本病理剖検輯報より，胆埕癌 2,808 例 を集積し，全腫湯に対する胆雚癌の比率は1.8\%である と記載した。杉浦と八木“) は第 9 回日本胆道外科研究会 アンケート調査報告において，胆道癌手術患者6,936例 の切除率は $49.4 \%$ ，手術死亡率は $10.4 \% ， 5$ 年生存率は $3.4 \%$ とた，自験例についてみると，昭和46年 1 月か ら昭和55年12月までの10年間に，当外科において手術ま たは経皮的胆管ドレナージを行った胆道癌は46例であっ た.このらち切除術を行いえたるのは，胆症癌は15例の $5 ち 9$ 例 $(60.0 \%)$, 䀒外胆管癌は22例の 万ち 5 例(22.7 $\%$ ，乳頭部癌は 9 例のらち 7 例 $(77.8 \%)$ て, 平均 45.7\%であった．外科胆道癌取扱い規約"により切除例 の stage 分類を行い, 手術法と生存期間との関連を子 ると表 3 と表 4 の如くであった. 手術死亡はないが, 5 年生存率は $19 \%$ であった. 5 年以上生存の 4 例のうち, stage II の乳頭部癌 の 1 例は䐗頭十二指腸切除術後 5 年 8 カ月で再発死亡したが, stage I の胆蕉癌 2 例と胆管 癌 1 例はさらに長期生存が望まれる. 胆竞癌の 1 例（表 3 , 第 1 例，65歳女）は摘出胆素の組織検查で粘膜癌が 発見されたむのである.これらの成績は，胆道癌は数が 少ないが，発見されたときは時期が遅く，切除率が低 く, 5 年生存率す低いので, 早期診断の必要なことを示 している.

胆变癌の早期診断は極めて困難であり ${ }^{5) \text {-10) }}$, 長期生存 が期待できるよらな䏣咅癌は手術によってはじめて発見 されるるのが大部分である゙). Shamiyeh"( は, PTC は胆 瘦の診断が確実たが，早期䛦断には貢献しないとして いる. 大藤ら ${ }^{6)} は$, 胆恋癌の各種検査法のなかで早期例 のスクリーニングに最む有用な検査法は経静脈胆道造影 
表 3 胆致密切除列

\begin{tabular}{|c|c|c|c|c|c|}
\hline 性，年 & 占居部位 & Stage & 手術法 & $\begin{array}{l}\text { 生存 } \\
\text { 期 }\end{array}$ & 転㷌 \\
\hline 1. 女. 65 & Gf & I & 胆夏摘出 $\mathrm{R}_{0}$ & 6 年 & 生 \\
\hline 2. 男, 68 & Gf & I & 胆票摘出 $\mathrm{R}_{1}$ & 5 年 1 月 & 生 \\
\hline 3. 男。 60 & Gf & I & 胆要摘出 $\mathbf{R}_{\mathbf{0}}$ & 1 年10月 & 生 \\
\hline 4. 女, 56 & Gbn & IV & 肝休切除 $R_{2}$ & 1 年 6 月 & 生 \\
\hline 5. 女. 87 & Gf & I & 胆摘出 $R_{0}$ & 1 年 & 生 \\
\hline 6. 男, 56 & Gf & III & 胆震摘出 $\mathbf{R}_{\mathbf{0}}$ & 1 年 5 月 & 死 \\
\hline 7. 女, 65 & Gfbn & IN & 胆震摘出 $R_{0}$ & 10 月 & 死 \\
\hline 8. 女, 66 & Gf & III & 䀒床切除 $\mathbf{R}_{\mathbf{0}}$ & 3月 & 死 \\
\hline 9. 男. 42 & Gfbn & IV & 胆霞摘出 $\mathrm{R}_{0}$ & 2 月 & 死 \\
\hline
\end{tabular}

表 4 胆管密 - 乳頭部密切除例

\begin{tabular}{|c|c|c|c|c|c|}
\hline 性, 年 & 占居部位 & Stage & 手術法 & $\begin{array}{l}\text { 告存 } \\
\text { 期 }\end{array}$ & 㤝㷌 \\
\hline 1. 女. 71 & 鿖流管 & I & 胆管切除 $R_{0}$ & 6 年 & 生 \\
\hline 2. 男, 64 & (Ad) & III & $\begin{array}{l}\text { 勝頭十二 } \\
\text { 指湯切除 } R_{2}\end{array}$ & 2 年 4 月 & 生 \\
\hline 3. 女, 71 & $\begin{array}{l}\text { 合流部 } \\
\text { 部 }\end{array}$ & I & 胆管切除 $R_{2}$ & 2 年 2 月 & 生 \\
\hline 4. 男, 61 & $\mathrm{Bi}$ & I & $\begin{array}{l}\text { 勝頭十二 } \\
\text { 指腸切除 } R_{1}\end{array}$ & 1 年 9 月 & 生 \\
\hline 5. 女， 64 & $\mathrm{Ab}$ & III & 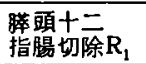 & 1 年 8 月 & 生 \\
\hline 6. 男, 44 & (Ad) & II & 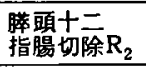 & 5 年 8 月 & 死 \\
\hline 7. 男， 44 & A & II & 乳頭部切除 & 2 年 7 月 & 死 \\
\hline 8. 男, 61 & (Ad) & III & 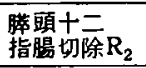 & 1 年 6 月 & 死 \\
\hline 9. 男， 49 & $\mathrm{Bi}$ & III & 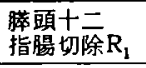 & 1 年 1 月 & 死 \\
\hline 10. 男， 58 & (Ad) & III & $\begin{array}{l}\text { 譬頭十二 } \\
\text { 指腸切 } \mathrm{R}_{1}\end{array}$ & 1 年 & 死 \\
\hline 11. 女, 57 & (Ad) & III & 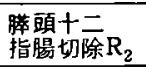 & 5 月 & 死 \\
\hline 12. 女, 76 & $\mathrm{Bm}$ & III & 胆管切除 $R_{1}$ & 5 月 & 死 \\
\hline
\end{tabular}

法であり，胆非の萎縮，辺緑の不整山凸，胆正陰性の場 合は早期胆蕰癌の可能性をるつ病变であるとしている. 症例 1 の如く胆咅底部が円く造影されないものも胆烡癌 の存在か㠜われる. 胆蓶癌は40歳以上が大部分である゙ ので，この年龄層以上の場合，排泄性胆道造影法て胆展 造影不良または胆童陰性を示す症例は，コンピューター 断層撮影，超音波検查， ERCP，PTC，直接胆䔖造影， 血管造影等の検查を追試する必要がある．予防的胆至摘 出術には賛否両論がある゙911ので，胆亳癌が疑われる 症例を手術するか，経過観察にするかは，上記諸検査所
見より総合的に判断すぺきである.

胆管癌は黄疸の発現した時点で診断することは困難 ではなく，ERCP やPTCによって確実に診断され $3^{6) 12) 19)}$. しかしながら，黄㾝発現時に診断されても，

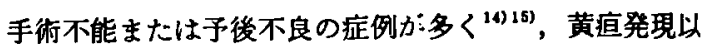
前の早期診断が望まれる.胆管癌では血清ビリルビン值 とAl-P 值の上昇が指摘されているが(19) 16), 症例 2 の如 く，LAP， $\gamma$-GTP 值の上昇む起こりらる.すなわち, 肝㙨能㭘查でビリルビン值の上昇がなくとも, 胆管系酵 素値の上昇を認めるむのは，経静脈胆道造影法，ERCP， PTC により肝外胆管の形態を䂓察する必要がある．胆 管壁の不整と㹟窄像は胆管癌を欵 万所見である。

早期胆至癌の定義については，腫陽の大きさに関係な く，粘膜内にとどまるものとする考之方と ${ }^{17}$, 固有筋層

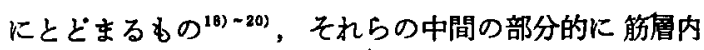
に限局性に浸潤するむの ，などの意見がある。また，

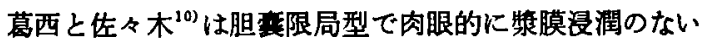
るのを早期癌としているが，漿膜下まで癌の浸潤の及ん だものはンン゚節転移が認められるものもあり，漿膜下 までの8 例では生存中は 2 例のみであるとしている.

Nevin $ら^{211}$ は胆癌の stage を5段階にわけ, stage I (粘膜内のみ) と stage II（粘膜と笳層に及ぶもの） は単純胆䙴摘出術で治度することを指摘した．粘膜筋板 を欠く胆垔で早期癌を定義することは困難であるが，現 時点では早期胆童癌は粘膜と筋㸴までにとどまるるのと することが妥当であろ5. 症例 1 は限局性ではあるが, 癌が墏膜下にも及んでおり早期癌とはいえないが，倣清 リンパ節には転移はなく，今後もさらに長期生存が望ま れる。

胆管は筋層が明白でなく，早期胆管㾔を規定するよい 規準はないよらである20). 症例 2 は三管合流部に限局し た癌で、肝十二指腸勒帯と漿膜に浸潤を認めす。リンハ 節転移も認めなかったので，此較的早期の胆管癌であ る.

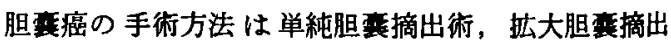
術，肝右葉切除術に三大別されるが，5 年生存率は単純

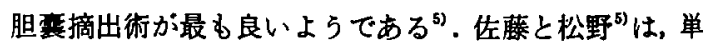
純胆垔摘出が 5 年生存率の良いのは手術後の組織学的精 查ではじめて癌と判明したすのが含まれていたためで， 術中あるいはそれ以前に癌と判明した場合は癌の深達度 を1つの指標として拡大胆芼摘出術，さらには肝右藮切 除術を行らべきであろらとしている.症例 1 は術前に胆 童癌と診断されたが，痹が胆王底に限局していたので， 
胆留摘出術にリンパ節成清を行って長期生存がえられ た. 肝知状切除術または肝右葉切除術を追加すべきか否 かは，癌の深達度のほかに占居部位す考虑すべきであろ う. 肝外胆管癌は占居部位と範囲により手術術式がおの ずから異るが，症例 2 のごとく三管合流部に限局したも のであれば胆垔と三管合流部胆管切除の適応であろう。

Piehler と Crichlow" は集計により, 胆童癌の術後 5 年生存率は 5,336 例の $4.1 \%$ であり, 5 年生存例は癌が 術中に明白でなかったものであったとしている．Nevin $ら^{21)}$ は stage I 症例の 5 年生存率は90.0\%で, stage II では58.9\%であったとしている.一方，杉浦と八木の報 告")では, 胆重癌 1,396 例のちち 5 年生存は70例 ( $5 \%$ ) であり，stage Iが87\%をしめている。また，胆管癌 （乳頭部癌を含まず）については，5年生存は1,623例 のちち47例 (2.9\%) にすぎず, stage I のむのが $48.9 \%$ をしめている．洋の東西を問わず，胆道癌手術の遠隔成 績は現時点では極めて不良であり, 手術成績の向上のた めに, stage I の時期に手術することが望ましく, 胆道 癌の早期診断が強く望まれる。

\section{総括}

1. 早期に術前 $X$ 線診断され，術後 5 年以上生存中の 胆虞と胆管癌の各 1 例を報告した。

2. 胆道癌手術の自験例と文献的考察により, 手術成 績を向上するには早期診断が不可欠で, 排泄性胆道造影 像の慎重な語影が重要である。また，胆管癌の早期診断 には血清ビリルビン值のみでなく, 胆管系酵素値の上昇 に注意する必要がある。

3. 胆道癌が疑われる症例には, 超音波検查, コンピ ュ一ター断層撮影, ERCP, PTC を積極的に行う必要が ある。

稿を䅂えるにあたり，中村俊彦検查科長（病理）の御 協力に感謝致します。

なお，症例 1 は第 146回日本消化器病学会関東甲信越 地方会に，症例 2 は第 15 回胆道疾患研究会において要旨 を発表した。

\section{文 献}

1) 日本胆道外科研究会：外科胆道癌取扱い規約. 金原出版, 1981 .

2) 本庄一夫 : 肝, 胆道および膵茂. 外科学下巻, 福田保監修，第 4 版，医学書院，595一 598， 1973.

3）金 清一, 石黒信吾, 大西俊造他 : $\alpha$-Fetoprote in 陽性を呈し診断困難であった胆侹癌の一剖
検例一本邦における過去10年間の 剖検胆王癌 2,808例の統計的考察を加味して一. 癌の臨床, $25: 1437-1442,1979$.

4）杉浦光雄, 八木義弘：アンケート調査報告：胆 萯及び胆管癌症例（乳頭部を含も）について。 第 9 回日本胆道外科 研究会 プロシーディンク ㅈ. 1981.

5) 佐藤寿雄, 松野正紀：阳道癌および膆癌手術の 遠隔成績, 外科診療, $18: 873-879,1976$.

6) 大藤正雄, 大野孝則，税所宏光他：早期癌の 診断と治療。胆・搭一診断. 外科診療, 18： 1184-1193, 1976.

7) T.A. Treadwell and W.J. Hardin: Primary carcinoma of the gallbladder: The role of adjunctive therapy in its treatment. Am. J. Surg., 132: 703-706, 1976.

8) F. Shamiyeh: Das primäre Gallenblasenkarzinom. Dtsch. med. Wschr., 99: 1583-1586, 1974.

9) J.M. Piehler and R.W. Crichlow: Primary carcinoma of the gallbladder. Surg. Gynecol. Obstet., 147: 929-942, 1978.

10）葛西洋一, 佐々木英制：早期の肝癌 - 胆瑟癌, 診断之治療, $68: 261$-266, 1980.

11) J. Lund: Surgical indications in cholelithiasis: Prophylactic cholecystectomy elucidated on the basis of long-term follow-up on 526 nonoperated cases. Ann. Surg., 151: 153-162, 1960.

12) W.V. McDermott and R.A. Peinert: Carcinoma in the supra-ampullary portion of the bile ducts. Surg. Gynecol. Obstet., 149: 681686, 1979.

13) C.D. Lees, A. Zapolanski, A.M. Cooperman, et al.: Carcinoma of the bile ducts. Surg. Gynecol. Obstet., 151: 193-198, 1980.

14) B. Savic, D. Schultz und E. Raschke: Die Carcinome des extrahepatischen biliären Systems: Mit einem Vorschlag zur Klassifizierung nach dem TNM-System. Langenbecks Arch. Chir., 331: 23-37, 1972.

15) H.J. Wanebo and O.F. Grimes: Cancer of the bile duct: The occult malignancy. Am. J. 
Surg., 130: 262-268, 1975.

16) 吉田晃治, 岡部正之, 内藤寿則他 : 胆管癌切除 症例の検討, $42: 1407-1417,1980$.

17) 榊原 宣, 小林政美, 川田彰得他 : 胆衰に未け 万早期癌, 外科治療, $30: 137-140,1974$.

18) 永光慎吾 : 胆道早期船の考方方, 臨床成人病, $6: 1193-1198,1976$.
19) 平井貞朗, 横溝清司, 才津秀樹他 : 胆重罊早期 症例, 外科診寮, $22: 1710-1714,1980$.

20）佐藤寿雄, 小山研二, 山内英生他 : 早期胆道癌 について, 外科, 42:1511-1518, 1980.

21) J.E. Nevin, T.J. Moran, S. Kay, et al.: Carcinoma of the gallbladder. Cancer, 37: 141148, 1976. 